\title{
Die opvoedkundige waarde van woordeboeke: Voorstelle vir woor- deboekonderrig in Suid-Afrika*
}

Michele F. van der Merwe, Fakulteit van Onderwys en Sosiale Wetenskappe, Kaapse Skiereiland Universiteit van Tegnologie, Wellington-kampus, Wellington, Republiek van Suid-Afrika (vandermerwem@cput.ac.za)

Opsomming: Die idee van woordeboekonderrig in die laerskool het nog nie baie aandag in die opvoedkunde en leksikografie in Suid-Afrika getrek nie. Tans word uitkomsgebaseerde onderrig as model in Suid-Afrikaanse skole gebruik en woordeboekonderrig kan baie goed binne dié opset geakkommodeer word. In die artikel word probeer om woordeboekonderrig te definieer en aangetoon watter uitkomste in verband met woordeboekgebruik deur leerders in die intermediêre fase bereik behoort te word. ' $n$ Model om die proses van woordeboekonderrig te illustreer, word aangebied. Praktiese voorbeelde van toepaslike woordeboeke vir gebruik in die klaskamer word bespreek. Die verwagting word gestel dat sowel opvoeders as ouers bewus moet word van die voordele van woordeboekgebruik en leerders moet aanmoedig om woordeboeke te gebruik.

Sleutelwoorde: WOORDEBOEKONDERRIG, OPVOEDKUNDE, LEKSIKOGRAFIE, UITKOMSGEBASEERDE ONDERRIG, KURRIKULUMVERKLARING, TAALHANDBOEK, WOORDEBOEKGEBRUIK, TAALVAARDIGHEID, TAALONDERRIG, HULPMIDDEL, WOORDEBOEKVAARDIGHEDE, WOORDEBOEKKULTUUR, NASLAANVAARDIGHEDE, PRIMÊRE NASLAANVAARDIGHEDE, SEKONDÊRE NASLAANVAARDIGHEDE, WOORDEBOEKFUNKSIES, WOORDEBOEKINLIGTING, BUITETEKS, WOORDEBOEKUITKOMSTE, OPVOEDKUNDIGE DOEL, PEDAGOGIESE WOORDEBOEK, SKOOLWOORDEBOEK, AANLEERDERWOORDEBOEK, INTERNETWOORDEBOEK, SELFOONWOORDEBOEK, TEKSRESEPSIE, TEKSPRODUKSIE, KOMMUNIKATIEWE FUNKSIE, KOGNITIEWE FUNKSIE.

\begin{abstract}
The Pedagogical Value of Dictionaries: Suggestions for Dictionary Education in South Africa. The idea of dictionary education in primary school has not attracted much attention in education and lexicography in South Africa. At present outcomesbased education is used as model in South African schools and dictionary education can be accommodated well within this framework. In the article, it is attempted to define dictionary education and to indicate which outcomes regarding dictionary use should be achieved by learners in the intermediate phase. A model to illustrate the process of dictionary education is presented. Practical examples of the use of appropriate dictionaries in the classroom are discussed. The

* Hierdie artikel is 'n Afrikaanse bewerking van 'n lesing "The Pedagogical Purpose of Dictionaries in South Africa: A Perspective on Dictionary Education" wat aangebied is by die Dertiende Internasionale Konferensie van die African Association for Lexicography, georganiseer deur die Buro van die Woordeboek van die Afrikaanse Taal, Stellenbosch, Republiek van Suid-Afrika, 30 Junie-2 Julie 2008.
\end{abstract}

Lexikos 19 (AFRILEX-reeks/series 19: 2009): 297-313 
expectations are set that educators as well as parents should become aware of the advantages of dictionary use and motivate learners to use dictionaries.

Keywords: DICTIONARY EDUCATION, EDUCATION, LEXICOGRAPHY, OUTCOMESBASED EDUCATION, CURRICULUM STATEMENT, LANGUAGE TEXT BOOK, DICTIONARY USE, LANGUAGE PROFICIENCY, LANGUAGE EDUCATION, TOOL, DICTIONARY SKILLS, DICTIONARY CULTURE, REFERENCE SKILLS, PRIMARY REFERENCE SKILLS, SECONDARY REFERENCE SKILLS, DICTIONARY FUNCTIONS, DICTIONARY INFORMATION, OUTER TEXT, DICTIONARY OUTCOMES, PEDAGOGICAL PURPOSE, PEDAGOGICAL DICTIONARY, SCHOOL DICTIONARY, LEARNER'S DICTIONARY, INTERNET DICTIONARY, CELL PHONE DICTIONARY, TEXT RECEPTION, TEXT PRODUCTION, COMMUNICATIVE FUNCTION, COGNITIVE FUNCTION.

\section{Inleiding}

Tydens ' $n$ ouervergadering by 'n laerskool noem die graad 1-opvoeder dat dit tyd geword het vir leerders om hulle eie woordeboeke te begin gebruik. Dié woordeboek wat bestaan uit 'n lys alledaagse, algemene woorde waarmee leerders in die grondslagfase te doen kry, kan gebruik word om dié woorde se spelling na te slaan. Die leerders kan ook hulle eie woorde waarmee hulle spelprobleme ondervind, met die hulp van die opvoeder tot die woordeboek byvoeg. Al begin die leerders die woordeboek in graad 1 saamstel, kan hulle dit deur die hele grondslagfase gebruik en bywerk. Een van die ouers bevraagteken toe die gebruik van 'n woordeboek omdat dit leerders sou aanmoedig om nie die spelling van woorde te leer as hulle dit so maklik in die woordeboek kan naslaan nie! Die vraag kan gestel word of dié kommentaar tekenend is van baie ouers, en ook die Suid-Afrikaanse samelewing se houding teenoor woordeboeke weerspieël. Koen (2008: 28) beweer tereg dat leerders so vroeg moontlik, reeds tydens die grondslagfase, aan die gebruik van 'n woordeboek bekendgestel moet word. Die aanleer van woordeboekvaardighede word as ' $n$ integrale deel van die ontwikkeling van leeselemente beskou. Koen (2008: 8) doen aan die hand dat 'n eenvoudige woordeboek deur opvoeders saamgestel word sodat leerders die alfabetiese stelsel kan aanleer. Sy definieer woordeboekvaardighede as die vermoë van leerders om letters en/of woorde te alfabetiseer, ' $n$ woord in 'n woordeboek na te slaan en om gidswoorde te gebruik.

Die doel van hierdie artikel is om die opvoedkundige waarde van woordeboeke te ondersoek en om opvoeders, opvoedingsinstansies, asook woordeboekuitgewers daarvan bewus te maak. Die volgende aspekte word in hierdie artikel onder die loep geneem:

- Wat is woordeboekonderrig?

- Die status van woordeboekonderrig in Suid-Afrika

- Wat is die voordele van woordeboekonderrig?

- Die proses van woordeboekonderrig 


\section{- Praktiese voorbeelde van woordeboekonderrig \\ - Die rol van opvoeders in woordeboekonderrig}

Die fokus van die artikel is op die onderrig van woordeboeknaslaanvaardighede in die laerskool. Voorvereistes hiervoor is kennis van die woordeboektipologie, die besef van die belangrikheid van naslaanvaardighede en die kennis van praktiese onderrigsituasies in die klaskamer. Maar het opvoeders die kennis, vaardighede en materiaal om woordeboekonderrig aan te bied? Taalhandboeke vir die laerskool voorsien nie inligting oor woordeboeknaslaanvaardighede nie en noem nie strategieë om woordeboekonderrig met taalkunde te integreer nie. Dié situasie kan die persepsie onder opvoeders laat ontstaan dat woordeboekonderrig nie so belangrik is soos taalverwerwing en die taalkundeprogram nie. Voorstelle word gedoen vir praktiese, uitkomsgebaseerde maniere om woordeboekonderrig aan te bied, asook voorbeelde van woordeboeke om te gebruik.

\section{Wat is woordeboekonderrig?}

Tydens ' $n$ taalonderrigprogram word 'n leerder se taalvaardigheid ten opsigte van praat, lees, skryf en luister verbeter. ' $n$ Woordeboek is een van die hulpmiddels beskikbaar aan die taalopvoeder om leerders te help om hulleself te kan help (Hartmann 1987: 181). Béjoint (1989: 212) wys daarop dat leerders wat weet hoe om woordeboeke te gebruik, beter in taaltake presteer as dié wat nie weet hoe om woordeboeke te gebruik nie. Volgens Herbst en Stein (1987: 116) is woordeboeke naslaanwerke, en soos in die geval van enige naslaansisteem, moet gebruikers sekere naslaanvaardighede kan toepas. Naslaanvaardighede kan deur volgehoue oefening aangeleer word en op skool met direkte leer deur opvoeders ingeskerp word. Naslaanvaardighede ontwikkel dus nie natuurlik nie, maar moet aangeleer word.

Die onderrig van naslaanvaardighede ten opsigte van woordeboeke maak 'n integrale deel van woordeboekonderrig uit. Gouws (2006: 79) wys daarop dat daar veral ses strukture van kernbelang is vir die suksesvolle en optimale onttrekking van inligting uit 'n skoolwoordeboek. Hierdie strukture is naamlik die dataverspreidingstruktuur, die toegangstruktuur, die makrostruktuur, die mikrostruktuur, die adresseringstruktuur en die mediostruktuur. Indien die genoemde strukture in ag geneem word, kan twee vlakke van naslaanvaardighede onderskei word, naamlik primêre en sekondêre naslaanvaardighede. Dit behoort aan leerders tydens woordeboekonderrig geleer te word. Primêre naslaanvaardighede verwys na die algemene toegang tot 'n woordeboek, dit wil sê kennis en gebruik van die toegangstruktuur (alfabetiese struktuur in die meeste gedrukte skoolwoordeboeke), of die toepas van algemene soekprosedures in aanlynwoordeboeke. Vir jonger leerders in die intermediêre fase vir wie selfs die gebruik van 'n alfabetiese toegangstruktuur problematies kan wees, moet opvoeders kennis van die alfabetvolgorde doelgerig en planmatig oordra. Dit sluit kennis tot die derde alfabetlettervolgorde in. 
Sekondêre naslaanvaardighede verwys na die verstaan van woordeboekspesifieke soekroetes om byvoorbeeld 'n toepaslike antwoord te vind op ' $n$ vraag gevra deur 'n leerder of 'n probleem gestel deur ' $n$ opvoeder. Die strukture verskil dus van woordeboek tot woordeboek. Dit sluit kennis van die dataverspreidingstruktuur, die makrostruktuur, die mikrostruktuur, die adresseringstruktuur en die mediostruktuur in. Voorbeelde van verskillende soekareas in 'n woordeboek is byvoorbeeld uitspraakinligting, betekenisinligting, grammatikale inligting, gebruiksfeerinligting en etimologiese inligting. Tipes buitetekste in skoolwoordeboeke wat vir leerders van groot waarde kan wees, byvoorbeeld lyste name van die Suid-Afrikaanse provinsies, ampstale, en hoofstede, en die uiteensetting van mate en gewigte, is ook woordeboekspesifiek. Sekondêre naslaanvaardighede kan woordeboekspesifiek, asook taalspesifiek wees.

Baie leerders is onbewus van die verskillende beskikbare woordeboeksoorte en sal enige soort woordeboek gebruik om 'n vraag te probeer beantwoord. Hulle sal na enige woordeboeksoort verwys as "die woordeboek", heeltemal onbewus van die spesifieke eienskappe van so 'n woordeboek. Kipfer (1987: 46) het met behulp van 'n vraelys onder Amerikaanse senior sekondêre studente bevind dat min van hulle die verskil tussen 'n tweetalige en 'n eentalige aanleerderwoordeboek kon verduidelik, asook die verskillende groottes van 'n standaard eentalige woordeboek. Kennis van woordeboektipologie sal opvoeders en leerders help om 'n toepaslike woordeboek te kies om sodoende hulle taalvrae op te los. Die aanleer van woordeboektipologie maak ' $n$ belangrike deel van woordeboekonderrig uit.

Woordeboekonderrig kan dus beskryf word as die onderrig van primêre en sekondêre naslaanvaardighede spesifiek aan 'n woordeboeksoort, asook die onderrig van woordeboektipologie. Uitkomste bereik sluit die suksesvolle gebruik van woordeboeke deur leerders in, wat impliseer dat hulle bevredigende antwoorde op hulle vrae oor byvoorbeeld uitspraak, betekenis, grammatika, gebruiksfeer en etimologie kon verkry. Woordeboekonderrig behoort op 'n natuurlike wyse met betrekking tot taalprobleme en inligtingsprobleme onderrig te word, ondersteun deur die gebruik van woordeboektekste en woordeboekverbandhoudende tekste. Onderskeid kan tussen woordeboekonderrig en taalonderrig gemaak word - eersgenoemde verwys na die optimale gebruik van 'n woordeboek, terwyl laasgenoemde verwys na uitkomste wat bereik moet word, byvoorbeeld in verband met korrekte taalgebruik, tydens die raadpleging van 'n woordeboek.

\section{Die status van woordeboekonderrig in Suid-Afrika}

Daar is tot dusver min navorsing oor woordeboekonderrig in Suid-Afrikaanse skole onderneem. Carstens (1995: 106) verwys na navorsing wat in Europa gedoen is en vergelyk dit met die toestand in Suid-Afrika. In 1995 was die situasie in Europese en Suid-Afrikaanse skole betreffende woordeboekonderrig min of meer dieselfde. Daar word in sillabusse gemeld dat leerders in staat 
moet wees om algemene naslaanwerke te kan gebruik, maar daar word geen melding van woordeboekonderrig of die onderrig van naslaanvaardighede gemaak nie. Volgens onlangse mondelinge mededelings vind woordeboekonderrig nie formeel in die volgende Europese lande in skole plaas nie: Engeland (M. Rundell 2008), België (S. Verlinde 2009) en Denemarke (S. Tarp 2009).

Béjoint (1989: 208) wys daarop dat talle skrywers in verskillende lande en tale die behoefte aan woordeboekonderrig beklemtoon: Flaherty (1923), Mathews (1964), Beattie (1973), Croft (1973), Barone (1979), Tono (1984), Hausmann (1986), Hartmann (1988) en Kühn (1987).

Met die instel van die Nasionale Kurrikulumverklaring in 2002 (NKV 2002) het die situasie betreffende die inhoud van taalsillabusse sedert 1995 in Suid-Afrika verander. In die 1995-sillabus is daar slegs genoem dat leerders in staat moet wees om algemene naslaanwerke te gebruik. In die NKV word daar wel in die verklaring ten opsigte van tale in die intermediêre en senior fases melding gemaak van uitkomste van woordeboekgebruik, naamlik dat leerders byvoorbeeld in staat moet wees om 'n woordeboek te kan benut om spelling en betekenis te kontroleer. Die volgende assesseringstandaarde kom onder Taalstruktuur en -gebruik in die intermediêre fase voor:

\begin{tabular}{|l|l|l|}
\hline Graad 4 & Graad 5 & Graad 6 \\
\hline $\begin{array}{c}\text { Teken woorde in 'n per- } \\
\text { soonlike woordeboek op }\end{array}$ & $\begin{array}{c}\text { Skep eie persoonlike } \\
\text { spellys }\end{array}$ & $\begin{array}{c}\text { Skep eie persoonlike } \\
\text { spellys }\end{array}$ \\
\hline $\begin{array}{c}\text { Toon ontwikkelende ken- } \\
\text { nis van die kompleksiteit } \\
\text { van alfabetiese volgorde }\end{array}$ & $\begin{array}{c}\text { Toon kennis van die kom- } \\
\text { pleksiteit van alfabetiese } \\
\text { volgorde waar die orde } \\
\text { volgens die 1ste letter } \\
\text { gegee word }\end{array}$ & $\begin{array}{c}\text { Toon kennis van die kom- } \\
\text { pleksiteit van alfabetiese } \\
\text { volgorde waar die orde } \\
\text { volgens die 2de letter } \\
\text { gegee word }\end{array}$ \\
\hline $\begin{array}{c}\text { Gaan spelling en betekenis } \\
\text { in 'n woordeboek na }\end{array}$ & $\begin{array}{c}\text { Gaan spelling en betekenis } \\
\text { in 'n woordeboek na }\end{array}$ & $\begin{array}{l}\text { Gaan spelling en betekenis } \\
\text { in 'n woordeboek of } \\
\text { tesourus na }\end{array}$ \\
\hline
\end{tabular}

Woordeboeke en tesourusse word ook as aanbevole tekste in die kurrikulumverklaring vermeld. Dit is ' $n$ verbetering op die vorige sillabus waar daar geen melding van woordeboekvaardighede gemaak is nie. Navorsing is egter nodig om vas te stel of die teorie in die praktyk toegepas word, hoe woordeboekgebruik in die klaskamer plaasvind, of woordeboekonderrig wel in die klaskamer voorkom en of taalhandboeke wat die NKV onderskryf, afdelings aan woordeboekonderrig afstaan.

\section{Wat is die voordele van woordeboekonderrig?}

Woordeboeke is waardevolle hulpmiddels in taalonderrig wat met vrug in die klaskamer aangewend kan word. Leerders kan hul taalvaardighede verbeter deur woordeboeke te ken en te gebruik. Opvoeders behoort 'n positiewe houding teenoor die gebruik van woordeboeke te kweek en leerders aan te moedig om woordeboeke aan te skaf en te raadpleeg. Verbeterde taalvaardigheid lei 
noodwendig tot verbeterde kommunikasie. In 'n veeltalige land soos SuidAfrika moet taal as inligtingsbron tussen gemeenskappe beklemtoon word en met die korrekte gebruik van veral vertalende woordeboeke kan hierdie uitkomste bereik word.

Woordeboeke kan ook as hulpmiddels vir leerders dien om hulle eie vordering en selfstandigheid te meet. Woordeboekgebruik bevorder onafhanklike denke en kweek selfvertroue gedurende die leerproses. Sodra 'n leerder ' $n$ woordeboek onafhanklik kan gebruik en die korrekte inligting vind, weet beide leerder en opvoeder dat daar reeds ' $n$ mate van vordering is. Indien 'n leerder byvoorbeeld in ' $n$ redelike mate ' $n$ tweede taal baasgeraak het, is dit vir hom/ haar makliker om ' $n$ woordeboek van die taal te raadpleeg as in die begin toe die taal aangeleer is.

Die doel van woordeboekonderrig is om leerders te leer om hulle woordeboeke op 'n gereelde grondslag te gebruik, asook vir die res van hulle lewens, om hulle sodoende vir lewenslange leer te bemagtig. Op so 'n wyse kan ' $n$ woordeboekkultuur in Suid-Afrika gevestig word. Gouws en Prinsloo (2005: 42) wys daarop dat die meeste Suid-Afrikaners hulle in 'n prewoordeboekkultuur bevind. Volgens Klein (2007: 418) kan die ontwikkeling van 'n woordeboekkultuur ruweg in drie fases verdeel word:

(1) lig mense in dat woordeboeke beskikbaar is;

(2) onderrig mense om woordeboeke effektief te gebruik; en

(3) aanvaar dat woordeboekgebruik iets normaals is, naamlik 'n alledaagse aktiwiteit wat leerders sowel by die skool as by die huis leer.

Die woordeboekonderrigscenario in Ghana is 'n goeie voorbeeld vir Afrika en Suid-Afrika om na te volg. In Ghana het elke leerder in primêre grade 4-6 (9-11 jaar) en elke student in senior sekondêre vlakke 1-3 (15-17 jaar) in Januarie 2008 'n woordeboek ontvang. Die Departement van Onderwys het 1,2 miljoen primêre en 600000 senior sekondêre woordeboekuitgawes voorsien (J. Luther 2008, mondelinge kommunikasie). Wanneer leerders inligtingsbronne soos woordeboeke besit, kan hulle hulleself beter bemagtig met kennis en die kanse is beter dat hulle suksesvoller in hulle studie kan wees.

\section{Die proses van woordeboekonderrig}

Woordeboekonderrig kan volgens die skrywer as 'n proses beskou en soos volg geillustreer word:

\begin{tabular}{|c|l|l|l|}
\hline $\begin{array}{c}\text { Identifiseer } \\
\text { uitkomste van } \\
\text { taalkurrikulum }\end{array}$ & $\begin{array}{l}\text { Vind toepaslike } \\
\text { woordeboek } \\
\text { na 'n kritiese } \\
\text { evaluering }\end{array}$ & $\begin{array}{l}\text { Metode van } \\
\text { onderrig } \\
\text { Woordeboek- } \\
\text { teks (inslui- } \\
\text { tend tesourus) } \\
\text { Taalteks }\end{array}$ & $\begin{array}{l}\text { 1. Woordeboeknaslaanvaardig- } \\
\text { hede (primêr en sekondêr) } \\
\text { 2. Woordeboektipologie } \\
\text { 3. Woordeboekfunksies } \\
\text { Uitkomste: Taalvaardighede }\end{array}$ \\
& & \\
\hline
\end{tabular}


Die proses kan soos volg uiteengesit word: In die kurrikulumverklaring (NKV 2002) word sekere taaluitkomste genoem wat die opvoeder as uitgangspunt in die klaskamersituasie gebruik, aangesien dit die standaarde is waarvolgens die leerder na onderrig geassesseer gaan word. Die opvoeder ondersoek verskillende woordeboeke op die mark en evalueer hulle krities om 'n toepaslike woordeboek te vind om in die klassituasie te gebruik. Die metode van onderrig in die klas sluit in die aanwending van woordeboektekste, taaltekste en ander tekste wat in die kurrikulum aanbeveel word (waar 'n woordeboek geraadpleeg kan word om inligting te verkry). Dit is belangrik om woordeboekonderrig op ' $n$ natuurlike wyse te gee en om woordeboeke en taaltekste te gebruik sodat leerders taal in 'n werklike kommunikasiesituasie kan ervaar. Die proses van woordeboekonderrig kan vir die huistaal gevolg word, maar ook, met sekere aanpassings, vir die addisionele taal. Tydens woordeboekonderrig word primêre en sekondêre woordeboeknaslaanvaardighede, woordeboektipologie en woordeboekfunksies geleer. 'n Leerder wat hierdie kennis bemeester het, is bemagtig om aan die uitkomste van taalvaardighede te voldoen soos in die NKV gestel.

Behalwe die spesifieke "woordeboekuitkomste" wat in die kurrikulumverklaring genoem word, is daar ook verskeie taaluitkomste in die kurrikulum wat met behulp van 'n woordeboek bereik kan word. Opvoeders behoort daarvan bewus te wees en moet woordeboeke daarvoor in die klaskamer aanwend, asook leerders aanmoedig om tuis woordeboeke te gebruik om die uitkomste te bereik. Die volgende assesseringstandaarde kom onder Taalstruktuur en -gebruik in die intermediêre fase voor:

\begin{tabular}{|c|c|c|}
\hline Graad 4 & Graad 5 & Graad 6 \\
\hline $\begin{array}{l}\text { Spel dikwels gebruikte } \\
\text { woorde korrek }\end{array}$ & $\begin{array}{l}\text { Spel dikwels gebruikte } \\
\text { woorde korrek en herken } \\
\text { uitsonderings in } \\
\text { spelpatrone }\end{array}$ & $\begin{array}{l}\text { Spel dikwels gebruikte } \\
\text { woorde korrek en herken } \\
\text { uitsonderings in } \\
\text { spelpatrone }\end{array}$ \\
\hline $\begin{array}{l}\text { Gebruik skryftekens doel- } \\
\text { treffend in alledaagse } \\
\text { woorde }\end{array}$ & $\begin{array}{l}\text { Gebruik skryftekens doel- } \\
\text { treffend in alledaagse } \\
\text { woorde }\end{array}$ & $\begin{array}{l}\text { Gebruik skryftekens doel- } \\
\text { treffend in alledaagse } \\
\text { woorde }\end{array}$ \\
\hline Gebruik hoofletters korrek & Gebruik hoofletters korrek & Gebruik hoofletters korrek \\
\hline $\begin{array}{l}\text { Herken korrekte woord- } \\
\text { verdelings }\end{array}$ & $\begin{array}{l}\text { Herken en gebruik korrekte } \\
\text { woordverdelings }\end{array}$ & $\begin{array}{l}\text { Herken en gebruik korrekte } \\
\text { woordverdelings }\end{array}$ \\
\hline $\begin{array}{l}\text { Ontwikkel woordeskat } \\
\text { deur woordfamilies en } \\
\text { woorde uit dieselfde veld } \\
\text { te herken }\end{array}$ & $\begin{array}{l}\text { Ontwikkel woordeskat } \\
\text { deur woordvorming, deur } \\
\text { woordfamilies en woorde } \\
\text { uit dieselfde veld te her- } \\
\text { ken en deur betekenis uit } \\
\text { die konteks af te lei }\end{array}$ & $\begin{array}{l}\text { Ontwikkel woordeskat } \\
\text { deur woordvorming, deur } \\
\text { woordfamilies en woorde } \\
\text { uit dieselfde veld te her- } \\
\text { ken en deur betekenis uit } \\
\text { die konteks af te lei }\end{array}$ \\
\hline $\begin{array}{l}\text { Ondersoek die herkoms } \\
\text { van woorde op 'n alge- } \\
\text { mene vlak (soos leen- } \\
\text { woorde) }\end{array}$ & $\begin{array}{l}\text { Begryp dat tale woorde by } \\
\text { mekaar leen en gebruik } \\
\text { nuutskeppinge }\end{array}$ & $\begin{array}{l}\text { Begryp dat tale woorde by } \\
\text { mekaar leen en gebruik } \\
\text { nuutskeppinge doeltref- } \\
\text { fend }\end{array}$ \\
\hline
\end{tabular}




\begin{tabular}{|c|c|c|}
\hline $\begin{array}{l}\text { Gebruik alledaagse } \\
\text { afkortings }\end{array}$ & $\begin{array}{l}\text { Gebruik alledaagse } \\
\text { afkortings en akronieme }\end{array}$ & $\begin{array}{l}\text { Gebruik 'n verskeidenheid } \\
\text { afkortings en akronieme }\end{array}$ \\
\hline $\begin{array}{l}\text { Verstaan en gebruik alle- } \\
\text { daagse adjektiewe: ver- } \\
\text { buiging, trappe van ver- } \\
\text { gelyking, intensiewe } \\
\text { vorme }\end{array}$ & $\begin{array}{l}\text { Verstaan die funksie en } \\
\text { gebruik van alledaagse } \\
\text { adjektiewe: verbuiging, } \\
\text { trappe van vergelyking, } \\
\text { intensiewe vorme, letter- } \\
\text { like en figuurlike } \\
\text { betekenis }\end{array}$ & $\begin{array}{l}\text { Verstaan die funksie en } \\
\text { gebruik van alledaagse } \\
\text { adjektiewe: verbuiging, } \\
\text { trappe van vergelyking, } \\
\text { intensiewe vorme, letter- } \\
\text { like en figuurlike } \\
\text { betekenis }\end{array}$ \\
\hline $\begin{array}{l}\text { Verstaan en gebruik alle- } \\
\text { daagse selfstandige naam- } \\
\text { woorde, asook getal, } \\
\text { geslag en verkleinwoorde }\end{array}$ & $\begin{array}{l}\text { Verstaan en gebruik alle- } \\
\text { daagse selfstandige naam- } \\
\text { woorde, asook getal, } \\
\text { geslag en verkleinwoorde }\end{array}$ & $\begin{array}{l}\text { Verstaan en gebruik alle- } \\
\text { daagse selfstandige } \\
\text { naamwoorde, asook getal, } \\
\text { geslag en verkleinwoorde }\end{array}$ \\
\hline $\begin{array}{l}\text { Gebruik alledaagse sino- } \\
\text { nieme, antonieme, homo- } \\
\text { nieme en homofone }\end{array}$ & $\begin{array}{l}\text { Verstaan en gebruik alle- } \\
\text { daagse sinonieme, anto- } \\
\text { nieme, homonieme en } \\
\text { homofone }\end{array}$ & $\begin{array}{l}\text { Verstaan en gebruik alle- } \\
\text { daagse sinonieme, anto- } \\
\text { nieme, homonieme en } \\
\text { homofone } \\
\end{array}$ \\
\hline $\begin{array}{l}\text { Gebruik die gepaste for- } \\
\text { maliteitsgraad (register) }\end{array}$ & $\begin{array}{l}\text { Gebruik taal met die ge- } \\
\text { paste formaliteitsgraad } \\
\text { (register) in minder be- } \\
\text { kende situasies en toon } \\
\text { bewustheid van teiken- } \\
\text { groep }\end{array}$ & $\begin{array}{l}\text { Gebruik taal met die ge- } \\
\text { paste register in minder } \\
\text { bekende en meer uitda- } \\
\text { gende situasies }\end{array}$ \\
\hline $\begin{array}{l}\text { Gebruik eenvoudige } \\
\text { idiomatiese uitdrukkings } \\
\text { korrek }\end{array}$ & $\begin{array}{l}\text { Toon kennis van die ge- } \\
\text { bruik van bekende idio- } \\
\text { matiese uitdrukkings }\end{array}$ & $\begin{array}{l}\text { Toon kennis van die ge- } \\
\text { bruik van 'n verskei- } \\
\text { denheid idiomatiese } \\
\text { uitdrukkings }\end{array}$ \\
\hline
\end{tabular}

Algemene taaluitkomste van woordeboekgebruik sluit dus in:
- Korrekte spelling
- Korrekte keuse van woorde
- Korrekte gebruik van idiome
- Korrekte uitspraak
- Korrekte gebruik van afkortings
- Uitbreiding van woordeskat
- Inligting oor die gebruik van 'n woord
- Semantiese inligting van ' $n$ woord
- Etimologiese inligting van ' $n$ woord
- Grammatikale inligting van 'n woord

Opvoeders, leerders en ouers moet bewus gemaak word van die groot hoeveelheid nuttige inligting in woordeboeke. Woordeboeke is houers van inligting, en kan dus effektief gebruik word om taal- en kommunikasieprobleme op 
te los. Reeds in die primêre fase moet leerders bewus gemaak word van die probleemoplossende potensiaal van woordeboeke sodat woordeboeke lewenslank gebruik kan word. Sodoende kan 'n woordeboekkultuur asook die ideaal van lewenslange leer gevestig word.

\section{Praktiese voorbeelde van woordeboekonderrig}

Gouws (2006: 73) wys daarop dat, alhoewel verskillende woordeboeksoorte gerig is op behoeftes ter bereiking van 'n opvoedkundige doel, daar binne die heersende woordeboektipologie 'n kategorie bestaan wat pertinent op hierdie doel gerig is, te wete die kategorie pedagogiese woordeboeke. Hierdie woordeboekkategorie sluit twee subkategorieë in, naamlik skoolwoordeboeke en aanleerderwoordeboeke. Skoolwoordeboeke wat op skoolleerders gerig is, maak voorsiening vir sowel moedertaal- as niemoedertaalsprekers van die behandelde taal. Aanleerderwoordeboeke is primêr gerig op die behoeftes van gebruikers wat 'n nuwe taal aanleer.

Vervolgens word voorbeelde uit die Nuwe Woordeboek Sonder Grense en die Oxford Afrikaans-Engels Skoolwoordeboek bespreek. Altwee woordeboeke beskik oor werkboeke waarin leerders woordeboeknaslaanvaardighede kan aanleer en wat deur opvoeders in die klaskamersituasie gebruik kan word. (Daar is nie tans 'n toepaslike Afrikaanse skoolwoordeboek vir huistaalleerders op laerskoolvlak op die mark wat bespreek kan word nie. Die Kernwoordeboek word as woordeboek vir leerders bemark, maar dit is nie geskik vir laerskoolleerders nie. Vergelyk byvoorbeeld die ingewikkelde definiëring van woorde soos rond en romp, asook die opname van talle onverklaarde lemmas soos ronddobber en rondswerf.) Die Oxford Afrikaans-Engels Skoolwoordeboek se teikengebruikersgroep word nie duidelik in die woordeboek gespesifiseer nie, maar Gouws en Tarp (2008: 67) maak die afleiding dat die woordeboek deur skoolleerders gebruik kan word wat Engels of Afrikaans as moedertaal bemeester het of wat Engels of Afrikaans as addisionele taal aanleer. Die Nuwe Woordeboek Sonder Grense is ' $n$ verklarende woordeboek ontwerp vir taalaanleerders van Afrikaans as addisionele taal. Dit ondersteun 'n handboekreeks vir graad 3 tot 12 . Een van die hierbo genoemde taalkundige inligtingstipes gaan bespreek word. Grammatikale inligting wat op 'n konsekwente wyse deur die woordeboek verskaf word, korreleer met die spesifieke woordeboekverwante taaluitkomste wat in die NKV uiteengesit word, naamlik verbuiging, trappe van vergelyking by adjektiewe, asook getal, geslag en verkleinwoorde by selfstandige naamwoorde. In die Nuwe Woordeboek Sonder Grense word die terminologie gebruik soos deur die Departement van Onderwys voorgeskryf, naamlik adjektief en selfstandige naamwoord.

Wanneer die lemmas moedeloos, moeg, moeilik en mooi in die onderstaande uittreksel uit die Nuwe Woordeboek Sonder Grense beskou word, kan gesien word dat die woorde as adjektiewe aangedui en die verbuiging en trappe van vergelyking telkemale verskaf word. (As 'n punt van kritiek kan genoem word dat 


\section{$\mathrm{Mm}$}

moed

$(-,-)$

As 'n mens moed het vir iets, sien jy

kans daarvoor en is jy nie bang nie.

$\Leftrightarrow$ Die span het nie moed [courage/heart]

verloor nadat hulle die wedstryd verloor het nie. $\Rightarrow$ Die onderwyser het baie moed [hope]

vir die klas, want hulle werk baie hard.

\section{moedeloos}

adjektief

(moedelose; moedeloser, die

moedeloosste)

lemand wat nie kans sien of krag het on

iets te doen nie, is moedeloos. $\Rightarrow \mathrm{Hv}$ is

baie moedeloos [dejected/despondent]

omdat hy nie die somme regkry nie. $\Rightarrow$ Die

vrou se kinders is baie stout; daarem is sy

gereeld moedeloos [dejected/discouraged].

moeder

naamwoord

(moeders, moedertijie)

Moeder is die formele woord vir ma.

$\Rightarrow$ Die seun se moeder [mother] het hom

altyd bygestaan totdat sy oorlede is.

\section{kyk ma en mamma}

teenoor vader

\section{moeè}

kyk moeg

moeg

- As 'n mens moeg is, het jy nie meer krag om aan te gaan nie. $\Rightarrow$ Ek is baie moeg [tired/exhausted] na die harde sokkeroefening. $\Rightarrow$ Die seuntiie was so moeg [tired] dat hy onmiddellik aan die slaap geraak het. 2. As 'n mens nie meer lus het vir iets nie, is jy moeg daarvoor. $\Rightarrow$ Ek is moeg [tired] vir die ou rok. $\Rightarrow$ Die onderwyseres is moeg [tired] daarvoor om goed te herhaal. moeilik adjektief

(moeilike; moeiliker, die moeilikste)

(1) As iets moeilik is, sukkel jv om dit te verstaan of te doen. $\Rightarrow$ Wiskunde was nog altyd een van my moeilikste [most difficult] vakke. $\Rightarrow$ Dit is 'n baie moeilike [difficult] onderwerp waaroor ons in groepe moet gesels.

teenoor maklik
(2) As iemand moeilik is, sukkel 'n mens om met hom/haar oor die weg te kom. $\Rightarrow$ Die skoolhoof sien gereeld moeilike [difficult] ouers en moeilike [difficult] kinders in sy kantoor. $\Rightarrow$ My ma was baie moeilik [cross/upset] toe ons so laat by die huis kom.

\section{eilikheid}

naamwoord

(moeilikhede, -)

(1) As 'n mens in die moeilikheid is, gaan jy probleme kry/hê. $\Rightarrow$ Rodney is al weer in die moeilikheid [trouble] omdat hy vrugte gesteel het. $\Rightarrow$ Daar was groot moeilikheid [trouble] by die skool nadat daar ' $n$ bakleiery was.

(2) As iets vir 'n mens moeilikheid gee, gee dit jou baie probleme. $\Rightarrow \mathrm{My}$ pa se ou bakkie wil omtrent nie meer ry nie en gee gereeld moeilikheid [trouble]. $\Rightarrow$ Goedkoop masjiene gee baie gou moeilikheid [trouble]. (3) As 'n mens moeilikheid het met iemand anders, kom julle nie oor die weg nie. $\Rightarrow$ Daar is altyd moeilikheid [trouble] as die twee broers bymekaar is moeit
naamwoord $(-,-)$

As 'n mens moeite doen, dan sit jy baie tyd en werk in iets. $\Rightarrow$ Die onderwyseres doen baie moeite [goes to a lot of trouble] met haar voorbereiding vir ons klasse. 5 Moenie so baie moeite [go out of your way] doen nie. Dis net 'n informele kuier.

\section{moenie} naamwoord

Moenie beteken jy mag/moet nie iets doen/sê nie. Dit is die verkorte vorm van moet nie. $\Rightarrow$ Moenie [don't] so haastig wees nie. Ons het baie tyd. $\Rightarrow$ Moenie [don't] so raas nie. Ek probeer slaap. kyk moet 3

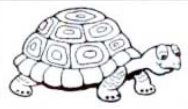
As jy moenie gebruik, moet daar nog 'n nie aan die einde van die sin kom. $\Rightarrow$ Moenie [don't] mors nie! $\Rightarrow$ Moenie [don't] altyd stry as ek met jou raas nie! 


\begin{tabular}{|c|c|}
\hline na & mooi \\
\hline \multicolumn{2}{|r|}{$\begin{array}{l}\text { mondfluitjie } \\
\text { (mondfluitjies, -) } \\
\text { 'n Mondfluitjie is 'n klein } \\
\text { musiekinstrument } \\
\text { wat 'n klank } \\
\text { maak as jy met jou } \\
\text { mond lug daarin blaas. } \Rightarrow \text { My oupa het } \\
\text { vroeër altyd op sy mondfluitjie [mouth- }\end{array}$} \\
\hline $\begin{array}{l}\text { jy kom eet. } \Rightarrow \text { Ek moes [had to] gister my } \\
\text { biblioteekboeke terugneem. } \\
\text { (2) As iets moet gebeur, is dit baie } \\
\text { belangrik dat dit gebeur. } \Rightarrow \text { Dit moet } \\
\text { [must] nou vinnig reën, want al die damme } \\
\text { is leeg. } \Rightarrow \text { Die vrou moes [had to] vinnig } \\
\text { rem trap om die hond te mis. } \\
\text { 3 Moet word saam met nie gebruik om } \\
\text { te wys dat iets nie mag gebeur nie. } \\
\text { Moenie is die verkorte vorm. } \Rightarrow \text { Moet [do } \\
\text { not/don't] asseblief nie so raas nie. Die } \\
\text { baba slaap. } \Rightarrow \text { Iy moet [must not] asseblief } \\
\text { nie jou skooltas skop nie. }\end{array}$ & $\begin{array}{l}\text { monster } \\
\text { (monsters, monstertjie) } \\
\text { ( 'n Monster is 'n karakter in sprokies } \\
\text { of verhale wat gewoonlik lelik is en vir } \\
\text { wie mens bang is. } \Rightarrow \text { Daar woon' } n \\
\text { monster [monster] onder die koning se } \\
\text { paleis. } \Rightarrow \text { Die monster [monster] in die } \\
\text { sprokie eet klein kindertiies. } \\
\text { 2) lemand wat lelik lyk of optree, is 'n } \\
\text { monster. } \Rightarrow \text { Die arme kind se ma is 'n } \\
\text { monster [monster]. } \Rightarrow \text { Ons het hierdie jaar } \\
\text { 'n monster [monster] vir 'n onderwyser. }\end{array}$ \\
\hline $\begin{array}{l}\text { Pasop: As jy moet } \\
\text { asseblief nie gebruik, } \\
\text { moet daar nog 'n nie aan } \\
\text { die einde van die sin kom. } \Rightarrow \text { Iy moet [must } \\
\text { not/shouldn't] asseblief nie so laat gaan } \\
\text { slaap nie. }\end{array}$ & $\begin{array}{l}\text { mooi adjektief } \\
\text { (mooi; mooier, die mooiste) } \\
\text { (1) As iemand/iets mooi is, hou 'n mens } \\
\text { daarvan om na die persoon/ding te kyk. } \\
\Rightarrow \text { Sjoe, maar dis 'n mooi [pretty] meisie! } \Rightarrow \\
\text { My ma het 'n baie mooi [beautiful] kers } \\
\text { gekoop. } \\
\text { (2) As 'n mens tevrede is met iets wat }\end{array}$ \\
\hline $\begin{array}{l}\text { mond naamwoord } \mathbf{m} \\
\text { (monde, mondjie) } \\
\text { o 'n Mens se mond is die opening in } \\
\text { jou gesig tussen jou lippe. } \Rightarrow \text { Die vrou sit } \\
\text { 'n happie kos op die vurk en dan in haar } \\
\text { mond [mouth]. } \Rightarrow \text { My boetie se mond } \\
\text { [mouth] is altyd vuil nadat hy geëet het. } \\
\text { (2) Die mond van 'n rivier is die plek } \\
\text { waar die rivier in die see in loop. } \Rightarrow \text { Ons } \\
\text { swem altyd by die mond [estuary] van die } \\
\text { rivier. }\end{array}$ & $\begin{array}{l}\Rightarrow \text { Mooi [well done], Zolile. Jy het die } \\
\text { oplossing gekry. } \Rightarrow \text { Die onderwyseres is trots } \\
\text { op haar span, want hulle het mooi [well] } \\
\text { gespeel. } \\
3 \text { As dit 'n mooi dag is, is die weer } \\
\text { lekker. } \Rightarrow \text { Ons het nou drie mooi } \\
\text { [fine/beautiful] dae na mekaar gehad. } \\
\Rightarrow \text { Dit is so 'n mooi [fine/beautiful] dag. } \\
\text { Kom ons gaan see toe. } \\
\text { sinoniem pragtig } \\
\text { teenoor lelik }\end{array}$ \\
\hline
\end{tabular}


daar in hierdie gevalle nie voorsiening gemaak is vir intensiewe vorme nie sodat woorde soos doodmoeg en popmooi nie opgeneem is nie.) Wanneer die lemmas moed, moeder, moeilikheid, moeite, mond, mondfluitjie en monster in die uittreksel uit die Nuwe Woordeboek Sonder Grense nagegaan word, blyk dit dat die woorde as selfstandige naamwoorde aangedui en die korrekte meervoudsvorm (of afwesigheid van 'n meervoudsvorm) en verkleiningsvorm telkens vermeld word. Dit is die soort inligting wat baie nuttig in 'n klaskamersituasie gebruik kan word.

Gegewe die vlak van die woordeboekkultuur in Suid-Afrika (Gouws 2006: 79) asook die beperkte toegang wat talle leerders tot woordeboeke het, gaan die leksikograwe in die beplanning van die meeste Suid-Afrikaanse skoolwoordeboeke van die standpunt uit dat die beplande woordeboek waarskynlik die enigste leksikografiese bron sal wees waarmee die tipiese lid van die teikengebruikersgroep in sy/haar skoolsituasie te doen sal kry. Gevolglik word skoolwoordeboeke nie slegs as monofunksionele bronne saamgestel nie. Die skoolwoordeboek wat op die behoeftes van die gemiddelde leerderteikengebruikersgroep gerig is, behoort volgens Gouws (2006: 79) sowel 'n kognitiewe as ' $n$ kommunikatiewe funksie te hê. In die nakoming van die kommunikatiewe funksie is die fokus op beide ' $n$ teksproduksie- en ' $n$ teksresepsiefunksie.

Tans word uitkomsgebaseerde taalhandboeke in Suid-Afrikaanse skole gebruik. 'n Nuwe generasie skoolhandboeke is saamgestel wat spesifiek gerig is op die bereiking van uitkomste wat met uitkomsgebaseerde onderwys geassosieer word. Wanneer die nuwe generasie graad 4-taalhandboeke (Sadie e.a. 2004, Van Oort en Mentz 2004 en Bloemhof e.a. 2005) met die ouer generasie standerd 2-taalhandboeke (De Klerk en Sadie 1971, Knoetze en Els 1981 en Van Niekerk e.a. 1983) vergelyk word, is dit duidelik dat die meerderheid nuwe generasie taalhandboeke nie meer naslaanbronne vir taalkundige inligting is nie. Die ouer generasie taalhandboeke het wel oor voldoende naslaanmateriaal beskik om aan leerders goeie taalkundige leiding te verskaf. In die nuwer generasie taalhandboeke word slegs 'n paar voorbeelde van verbuiging, trappe van vergelyking, intensiewe vorme, meervoudsvorme en verkleiningsvorme gelys. Woordeboeke as houers van taalkundige inligting oortref dus die huidige generasie taalhandboeke as naslaanbronne. Leerders en hulle ouers en opvoeders behoort bewus te wees van die probleemoplossende potensiaal van woordeboeke.

Die Suid-Afrikaanse kurrikulum is baie gefokus op kommunikasievaardighede sodat leerders geleer word om goeie verbale kommunikeerders te wees, maar skryfvaardighede, veral spelvaardighede word afgeskeep. Daar word daagliks berig oor die lae geletterdheidsvlakke onder Suid-Afrikaanse leerders (Koen 2008). Koen (2008: 28) wys op die swak prestasie van Suid-Afrikaanse leerders ten opsigte van basiese leesvaardighede, soos uiteengesit in 2007 in die publikasie van die navorsingsresultate van die Universiteit van Pretoria. ' $n$ Onlangse verslag deur die TIMSS and PIRLS International Study Center dui aan dat $80 \%$ van Suid-Afrikaanse kinders wat by die Sentrum vir Evaluasie en Assessering (UP) getoets is, nie oor basiese leesvaardighede 
beskik nie (sien Koen 2008: 28). Suid-Afrika se graad 4- en graad 5-leerders het die swakste gevaar uit die 40 lande wat deelgeneem het.

Aangesien baie leerders spelprobleme ondervind, kan woordeboekgebruik, saam met ander opvoedkundige strategieë, 'n rol speel as hulpmiddel om sulke probleme op te los. Die Oxford Afrikaans-Engels Skoolwoordeboek bevat ook 'n naslaanafdeling met onder andere spel- en punktuasiereëls in Afrikaans. Dié naslaanafdeling wat naas die sentrale teks verskaf word, vorm deel van die middelteks van die woordeboek. Gesien die teikengroepgebruikers van die woordeboek wat jong leerders is wat leiding nodig het ten opsigte van spelreëls en spelbeginsels, kan dit van groot waarde vir hulle wees.

Woordeboeke is draers van inligting - hulle dien nie slegs as taalkundige handleidings nie, maar ook as buitetalige naslaanbronne. Gouws (2009) stel vakwoordeboeke vir laerskoolleerders voor waar vakwoorde 'n primêre kognitiewe funksie het. Die Oxford Afrikaans-Engels Skoolwoordeboek maak voorsiening vir vakterminologie wat in die laerskool gebruik word. In dié geval word dus sowel vakkundige as taalkundige inligting oorgedra. Dit het byvoorbeeld woorde soos begroting, begroot, behoefte en belasting opgeneem. Dit is terme wat in die Ekonomiese en Bestuurswetenskappekurrikulum vir graad 4 voorkom. Wanneer leerders met 'n term in die Ekonomiese en Bestuurswetenskappeklas gekonfronteer word wat hulle nie verstaan nie, kan die betekenis maklik in 'n woordeboek opgesoek word. Voorbeeldsinne soos die volgende in die Oxford Afrikaans-Engels Skoolwoordeboek tree verhelderend op:

Die skool het begroot om 'n swembad te bou.

Daar is nie geld in my begroting vir 'n DVD-speler nie.

Die skool het ' $n$ behoefte aan 'n groter biblioteek.

'n Mens moet belasting betaal op jou salaris.

Internetwoordeboeke kan 'n groot rol speel om 'n woordeboekkultuur onder laerskoolleerders te vestig. Die jonger generasie hou van rekenaars, is daarmee vertroud en beskou dit as deel van hulle alledaagse lewe. Wanneer leerders internetwoordeboeke gebruik, het hulle ander soort naslaanvaardighede (soekvaardighede) nodig as wat die geval is by gedrukte woordeboeke. Die eindresultaat van die soektog is belangrik en die veronderstelling is dat die leerders die inligting sal kry waarvoor hulle soek. Talle uitgewers het internetwoordeboeke beskikbaar, wat in sekere gevalle selfs gratis geraadpleeg kan word (vergelyk byvoorbeeld Merriam-Webster in hierdie verband). Daar is nog nie internetwoordeboeke vir Afrikaanse laerskoolleerders beskikbaar nie. Taaloefeninge in die vorm van taalspeletjies dien as aantrekkingskrag vir jong gebruikers om hulle aan te moedig om woordeboeke te gebruik (vergelyk byvoorbeeld die webwerf van Merriam-Webster).

Die uitgewer Pharos het 'n nuwe dimensie aan leksikografie in Suid-Afrika verleen met 'n woordeboek wat op 'n selfoon gelaai kan word. Suid-Afrika se eerste tweetalige woordeboek vir selfone Klein Woordeboek/Little Dictionary is 
in Julie 2008 bekendgestel. So 'n woordeboek kan maklik geraadpleeg word, aangesien dit oral saamgedra kan word. In veral plattelandse gebiede waar inligtingsbronne skaars is, kan 'n selfoonwoordeboek 'n nuttige inligtingsbron wees. Aangesien $90 \%$ van Suid-Afrika se bevolking toegang tot selfone het, kan dit 'n groot rol speel in die skep van 'n woordeboekkultuur (W. Smith-Muller 2008, mondelinge mededeling).

\section{Die rol van opvoeders in woordeboekonderrig}

Combrink e.a. (1997: 13) beskou visuele materiaal en naslaanbronne as basiese onderrig- en leermateriaal wat vir interaktiewe onderrig- en leerprogramme in elke klas beskikbaar behoort te wees. Onder naslaanbronne (Combrink e.a. 1997: 13) word die volgende genoem: die Afrikaanse Woordelys en Spelreëls, verklarende en vertalende woordeboeke, 'n uitspraakwoordeboek, 'n etimologiese woordeboek, 'n idioomwoordeboek en 'n voorsetselwoordeboek. Woordeboeke behoort in elke klaskamer teenwoordig te wees ten einde goeie taalonderrig te verseker. Die vraag is hoeveel klaskamers in Suid-Afrika oor selfs 'n enkele woordeboek beskik.

Is opvoeders bewus van die belangrikheid van woordeboekgebruik en woordeboekonderrig, en die rol wat dit in taal-, veral in taalkundeonderrig speel? In die Suid-Afrikaanse konteks van veeltaligheid vervul taalkundeonderrig 'n belangrike rol om suksesvolle kommunikasie tussen mense te verseker. Indien ' $n$ leerder goed in sy huistaal onderrig word, word 'n goeie grondslag vir woordeboekgebruik gelê. Indien woordeboekgebruik in die klaskamer aangeleer word, word 'n goeie basis vir die verwerwing van 'n nuwe taal gevorm.

Sekere opvoeders in Suid-Afrika is nie voldoende gekwalifiseer om taalkunde aan te bied nie en die meerderheid is nie opgelei in basiese woordeboektipologie en -gebruik nie. Dit sal dus heeltemal verstaanbaar wees as hulle nie die noodsaaklikheid van woordeboekonderrig as deel van taalonderrig insien nie. Leksikografie vorm nie normaalweg deel van die universiteitsopleiding vir opvoeders nie. Dit beteken dat opvoeders nie opleiding ontvang ten opsigte van woordeboektipologie, woordeboekfunksies, leksikale velde (sinonieme, antonieme) en leksikale items (subleksikale items en multileksikale items) nie. Dit kan ook die gevolg hê dat opvoeders nie geleer word om 'n kritiese instelling teenoor woordeboeke te ontwikkel nie. Gevolglik beskik hulle nie altyd oor genoeg kennis om 'n ingeligte keuse oor 'n gepaste woordeboek vir die klassituasie te maak nie. Opvoeders moet ook woordeboeke wat leerders tuis kan gebruik, aan ouers kan aanbeveel. Wanneer woordeboeke gekies word, moet opvoeders seker maak van die funksie van die woordeboek wat leerders benodig. Gaan 'n woordeboek vir teksontvangs, teksproduksie of vir vertaling gebruik word? Gouws (2006: 75) wys daarop dat daar twee tipes funksies binne die teorie van leksikografiese funksies bestaan, naamlik kognitiewe en kommunikatiewe funksies. Die doel van kognitiewe funksies (vroeër 
bekend as kennisgerigte funksies) is om die gebruiker te help met algemene en ensiklopediese data, data oor spesifieke vakgebiede en data oor taal. Kommunikatiewe funksies ondersteun gebruikers met die oplos van probleme betreffende teksproduksie in die moeder- en vreemde taal, asook die vertaling van tekste uit die moeder- in die vreemde taal en omgekeerd.

Alhoewel uitkomste van woordeboekgebruik in die NKV van die intermediêre en senior fases voorkom, hoef dit nie noodwendig tot woordeboekgebruik en woordeboekonderrig in laerskole te lei nie. Allerlei ander praktiese probleme kan in die weg staan van suksesvolle woordeboekgebruik en woordeboekonderrig, naamlik die gebrek aan 'n geskikte skoolwoordeboek om in die klaskamer te gebruik, of die beperkte toegang tot bronne omdat nie alle leerders oor hulle eie woordeboeke beskik nie en nie alle klaskamers van woordeboeke voorsien is nie. Die moontlikheid bestaan ook dat dit die assesseer van woordeboekuitkomste kan bemoeilik. Indien daar nie genoeg woordeboeke vir elke leerder in die klaskamer beskikbaar is nie, is assessering prakties byna onmoontlik.

Dit word sterk aanbeveel dat die Departement van Nasionale Opvoeding 'n opleidings- en bewusmakingsveldtog ten opsigte van woordeboekonderrig loods. Opvoeders, en hulle sluit volgens Klein (2007: 420) taalopvoeders en vakopvoeders in, behoort 'n deeglike kennis van woordeboeke te hê en behoort woordeboeke met selfvertroue te kan gebruik. Woordeboekonderrig behoort as deel van die opleiding van opvoeders op universiteitsvlak ingesluit te word en opvoeders in diens behoort ook opleiding te ontvang. Klein (2007: 420) is van mening dat inligting oor (a) die voordele van woordeboeke vir die individuele spreker, (b) inligting oor die verskillende woordeboektipes, (c) die inhoud van 'n woordeboek, (d) die prosedures om inligting uit 'n woordeboek te onttrek, en (e) die metodes om die inligting toe te pas deel van so 'n kursus behoort uit te maak. Die volgende kan daarby gevoeg word: inligting oor woordeboekfunksies en naslaanvaardighede, asook die uitkomste van woordeboekonderrig en die onderrigmetodologie van woordeboekgebruik.

Opvoeders kan 'n belangrike rol speel om 'n woordeboekkultuur in SuidAfrika te vestig. Omdat hulle 'n groot invloed op leerders het, kan hulle leerders sodoende bewus maak van die waarde van woordeboeke. Woordeboekonderrig is belangrik in die laerskool waar die jong geslag leerders woordeboekvaardighede bygebring kan word sodat hulle die waarde van woordeboeke kan besef. Leerders behoort in die gewoonte te kom om gereeld woordeboeke te raadpleeg tydens teksresepsie (bv. lees) en teksproduksie (bv. praat en skryf, en woordspeletjies en blokkiesraaisels) - die begin van 'n lewenslange verhouding met woordeboeke.

\section{Gevolgtrekking}

Woordeboekonderrig vorm ' $n$ belangrike aspek van taalonderrig wat aandag in die klaskamer moet kry, maar ook die aandag van opvoedkundiges, die De- 
partement van Nasionale Opvoeding, uitgewers en leksikograwe verdien. Soos in die artikel aangetoon, vorm woordeboekonderrig reeds deel van die NKV. Nie net is woordeboekonderrig gedefinieer nie, maar daar is ook aangetoon watter uitkomste in verband met woordeboekonderrig in die laerskool bereik behoort te word. ' $n$ Model ter illustrasie van die proses van woordeboekonderrig is voorgestel.

Woordeboeke as naslaanbronne is uitstekende bronne van kennis vir laerskoolleerders en dit is sowel opvoeders as ouers se plig om leerders daarvan bewus te maak. Sodoende kan 'n woordeboekkultuur in Suid-Afrika tot stand kom.

\section{Bibliografie}

Barone, R. 1979. On the Use of the Advanced Learner's Dictionary of Current English: From Theory to Practice. Rassegna Italiana di Linguistica Applicata 11(1-2): 187-194.

Beattie, N. 1973. Teaching Dictionary Use. Modern Languages 54(4): 161-168.

Béjoint, H. 1989. The Teaching of Dictionary Use: Present and Future Tasks. Hausmann, F.J., O. Reichmann, H.E. Wiegand en L. Zgusta (Reds.). 1989-1991. Wörterbücher. Ein internationales Handbuch zur Lexikographie/Dictionaries. An International Encyclopedia of Lexicography/Dictionnaires. Encyclopédie internationale de lexicographie: 208-212. Berlyn/New York: Walter de Gruyter.

Bloemhof, F., S. Erasmus, B. Rau, J. Reid en J. van Lill. 2005. Leerplatform Afrikaans Graad 4. Kaapstad: Nasou via Afrika.

Carstens, A. 1995. Language Teaching and Dictionary Use: An Overview. Lexikos 5: 105-116.

Combrink, L., N. Faasen, H. Geyser en A. Kloppers. 1997. Taalkonteks. Kenwyn: Juta.

Cowie, A.P. (Red.). 1987. The Dictionary and the Language Learner. Tübingen: Max Niemeyer.

Croft, K. 1973. Dictionary Use in ESL Courses. TESL Reporter 7(1): 1-9.

De Klerk, P.F. en J.J. van L. Sadie. 1980. Afrikaans my taal Standerd 2. Kaapstad: Maskew Miller.

Flaherty, M.C. 1923. How to Use the Dictionary. New York: Ronald Press.

Gouws, R.H., M. Stark en L. Gouws. 2004. Nuwe Woordeboek Sonder Grense. Kaapstad: Maskew Miller Longman.

Gouws, R.H. en D.J. Prinsloo. 2005. Principles and Practice of South African Lexicography. Stellenbosch: SUN PReSS.

Gouws, R.H. 2006. Leerdergedrewe leksikografie. Tydskrif vir Taalonderrig 40(1): 72-84.

Gouws, R.H. en S. Tarp. 2008. A New Step Forward for South African Learners' Lexicography: The Oxford Afrikaans-Engels/English-Afrikaans Skoolwoordeboek/School Dictionary. Tydskrif vir Taalonderrig 42(1): 65-79.

Gouws, R.H. 2009. Geïntegreerde woordeboekgebruik van vakwoordeboeke vir aanleerders. Lexikos 19: 72-93.

Hartmann, R.R.K. 1987. Dictionaries of English: The User's Perspective. Bailey, R.W. (Red.). 1987. Dictionaries of English: Prospects for the Record of Our Language: 121-135.

Hartmann, R.R.K. 1988. The Learner's Dictionary: Traum oder Wirklichkeit? Hyldgaard-Jensen, K. en A. Zettersten (Reds.). 1988. Symposium on Lexicography III. Proceedings of the Third International Symposium on Lexicography, May 14-16, 1986 at the University of Copenhagen: 215-235. Tübingen: Max Niemeyer. 
Hausmann, F.J. 1986. The Training and Professional Development of Lexicographers in Germany. Ilson, R. (Red.). 1986. Lexicography. An Emerging International Profession: 101-110. Manchester: Manchester University Press.

Herbst, T. en G. Stein. 1987. Dictionary Using Skills: A Plea for a New Orientation in Language Teaching. Cowie, A.P. (Red.). 1987: 115-128.

Kipfer, B. 1987. Dictionaries and the Intermediate Student: Communicative Needs and the Development of User Reference Skills. Cowie, A.P. (Red.). 1987: 44-54.

Klein, J. 2007. Implementing a Dictionary Culture in South Africa: An Attempt at a General Framework for the African Languages. Lexikos 17: 416-423.

Knoetze, F.L. en J.S.M. Els. 1981. Keurige Afrikaans St. 2. Tweede uitgawe. Goodwood: Nasou.

Koen, M. 2008. Bemagtig opvoeders vir onmiddellike mobilisasie van grondslagfase-leerders se geletterdheid. Litnet Akademies 5(2): 27-45.

Kühn, P. 1987. Mit dem Wörterbuch arbeiten. Eine Einführung in die Didaktik und Methodik der Wörterbuchbenutzung. Bonn/Bad Godesberg: Dürr.

Louw, P. (Red.) 2007. Oxford Afrikaans-Engels/English-Afrikaans Skoolwoordeboek/School Dictionary. Kaapstad: Oxford University Press.

Mathews, M.M. 1964. The Freshman and his Dictionary. Allen, H.B. (Red.). 1964. Readings in Applied English Linguistics: 372-375. New York: Appleton Century Crofts.

Merriam-Webster [aanlyn]. http:/ /WordCentral.com.

Odendal, F.F. 2000. Kernwoordeboek. Kaapstad: Perskor.

Republiek van Suid-Afrika. Departement van Onderwys. 2002. Hersiene Nasionale Kurrikulumverklaring Graad R-9 (Skole). Beleid Tale. Afrikaans Huistaal. Pretoria: Departement van Onderwys.

Sadie, J.J. van L., W. Louw, A. Engelbrecht en M. Mihai. 2004. Afrikaans ons taal graad 4. Kaapstad: Maskew Miller Longman.

Tono, Y. 1984. On the Dictionary User's Reference Skills. Ongepubliseerde B.Ed.-skripsie. Tokio: Gakugei Universiteit.

Van Niekerk, A.P., J.J. Steyn, W.H. Herman en J. Vosloo. 1983. Afrikaans vir vandag Standerd 2. Kaapstad: Juta.

Van Oort, R. en W. Mentz. 2004. Afrikaans in aksie Graad 4. Kaapstad: Kagiso Education. 